\title{
Mitsuaria chitosanitabida gen. nov., sp. nov., an aerobic, chitosanase-producing member of the 'Betaproteobacteria'
}

Correspondence

Makoto Kawamukai

kawamuka@life.shimane-u.ac.jp

\author{
Daiki Amakata, ${ }^{1}$ Yasuhiro Matsuo, ${ }^{1}$ Kumiko Shimono, ${ }^{1}$ Jae Kweon Park, ${ }^{1}$ \\ Choong Soo Yun, ${ }^{1}$ Hideyuki Matsuda, ${ }^{1}$ Akira Yokota ${ }^{2}$ \\ and Makoto Kawamukai ${ }^{1}$
}

\author{
${ }^{1}$ Department of Life Science and Biotechnology, Faculty of Life and Environmental Science, \\ Shimane University, 1060 Nishikawatsu, Matsue, Shimane 690-8504, Japan \\ ${ }^{2}$ Institute of Molecular and Cellular Biosciences, The University of Tokyo, 1-1-1 Yayoi, \\ Bunkyo-ku, Tokyo 113, Japan
}

Four strains $\left(3001^{\top}, 2,12\right.$ and 13), which were isolated as chitosanase-producing bacteria from soil from Matsue city (Japan), were studied phenotypically, genotypically and phylogenetically. Based on sequence analysis of 16S rRNA genes, DNA G + C content (67.4-69.2 mol\%), quinone type (UQ-8), major fatty acid composition (3-OH $10: 0,3-\mathrm{OH} 14: 0)$ and other phylogenetic studies, strains $3001^{\top}, 12$ and 13 were found to occupy a separate position in the 'Betaproteobacteria'. Roseateles depolymerans, Rubrivivax gelatinosus and Ideonella dechloratans were their closest neighbours (93-95\% 16S rRNA gene sequence similarity). The 16S rRNA gene sequence and other characteristics suggested that strain 2 belonged to the genus Flavobacterium. DNA-DNA hybridization experiments supported the conclusion that strains $3001^{\top}, 12$ and 13 were of the same species (72-78\% DNA hybridization) and only distantly related to $I$. dechloratans and $R$. gelatinosus. It is proposed that strains $3001^{\top}, 12$ and 13 represent a novel genus and species for which the name Mitsuaria chitosanitabida gen. nov., sp. nov. is proposed. The type strain of Mitsuaria chitosanitabida is $3001^{\top}\left(=\mathrm{IAM} 14711^{\top}=\mathrm{ATCC}^{\circ}\right.$ BAA $\left.-476^{\top}\right)$.
The 'Betaproteobacteria' includes the families Comamonadaceae, Alcaligenaceae and Neisseriaceae, the genera Burkholderia, Ralstonia and Rhodocyclus, ammonia-oxidizing bacteria and other species. The Comamonadaceae originally contained Variovorax (Willems et al., 1991b), the purple non-sulfur bacteria, including Rubrivivax and Rhodoferax (Hiraishi, 1994; Willems et al., 1991a), and other genera such as Comamonas and Acidovorax, formerly described as Pseudomonas (Willems et al., 1991b, 1992). The genus Aquabacterium (Kalmbach et al., 1999), the bacteriochlorophyll a-containing bacteria Roseateles (Suyama et al., 1998, 1999) and sheathed bacteria, including Leptothrix and Sphaerotilus (Siering \& Ghiorse, 1996), are closely related to the above genera. Besides these well-characterized species, it is thought that there are many more as yet unknown species that belong to the 'Betaproteobacteria'.

Published online ahead of print on 6 May 2005 as DOI 10.1099/ ijs.0.63629-0.

Abbreviations: MK, menaquinone; UQ, ubiquinone.

The GenBank/EMBL/DDBJ accession numbers for the 16S rRNA gene sequences of strains $3001^{\top}, 2,12$ and 13 are $A B 006851$, AY856841, AB024307 and AB024306, respectively.
The present study was undertaken to determine the taxonomic position of certain novel strains that were originally isolated as chitosanase-producing bacteria and classified in the 'Betaproteobacteria'. We present evidence that the newly isolated strains $3001^{\mathrm{T}}, 12$ and 13 should be classified as a new genus and species, Mitsuaria chitosanitabida gen. nov., sp. nov.

We screened soils from Matsue city, Japan, for bacteria producing chitosanase, an enzyme which degrades glucosamine polymers and forms clear zones on a chitosan-containing minimal medium. This defined medium consisted of $1 \%$ colloidal chitosan, $0.025 \%$ yeast extract, $0.025 \%$ peptone, $0.025 \% \mathrm{~K}_{2} \mathrm{HPO}_{4}, 0.07 \% \mathrm{KH}_{2} \mathrm{PO}_{4}$ and $0.03 \% \quad \mathrm{MgSO}_{4}$. About 30 strains were found that formed clear zones on the colloidal chitosan medium. From these, four strains $\left(3001^{\mathrm{T}}\right.$, 2, 12 and 13) that produced good clear zones were chosen for further study.

Strain $3001^{\mathrm{T}}$ has been studied extensively. The chitosanase produced by strain $3001^{\mathrm{T}}$ has already been purified and characterized and the corresponding gene has been cloned (Park et al., 1999). Further analyses on this chitosanase have been conducted (Shimono et al., 2002a, b; Yun et al., 2005). 


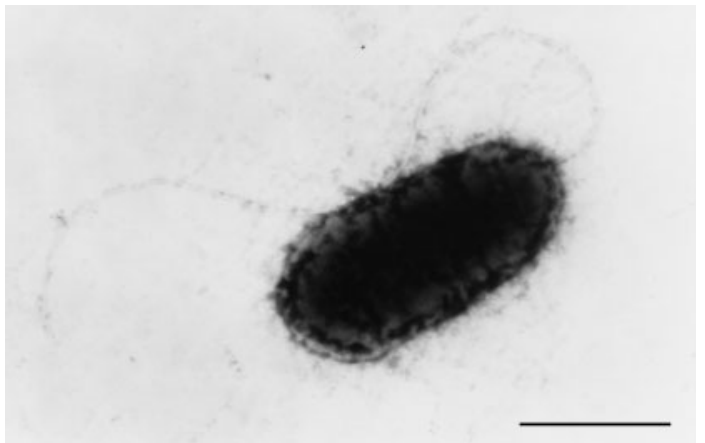

Fig. 1. Cell morphology of strain $3001^{\top}$ observed by transmission electron microscopy after negative staining. Bar, $1 \mu \mathrm{m}$.

For these studies, strain $3001^{\mathrm{T}}$ was tentatively named 'Matsuebacter chitosanotabidus' 3001, but here we propose the name Mitsuaria chitosanitabida gen. nov., sp. nov.

The cell morphology of strain $3001^{\mathrm{T}}$ was observed by phasecontrast and transmission electron microscopy. Some cells were straight and elongated and some were rod-shaped. Cells varied between $0 \cdot 7$ and $1.0 \mu \mathrm{m}$ in width and $2 \cdot 0$ and
$4 \cdot 0 \mu \mathrm{m}$ in length. Cells were actively motile with a single polar flagellum. Flagellation was examined by transmission electron microscopy (JEOL 1210; JEOL) after negative staining with $1 \%(\mathrm{w} / \mathrm{v})$ phosphotungstic acid (Fig. 1). The motile strain was rod-shaped. No sheath was detected by electron microscopy. Endospores were not produced. The Gram reaction was negative. No fluorescent pigments were produced. Strain $3001^{\mathrm{T}}$ showed aerobic respiration with oxygen as the final electron acceptor. Catalase and oxidase were produced. Strain $3001^{\mathrm{T}}$ could not grow photosynthetically under light conditions or under anaerobic dark fermentation conditions. Additional physiological properties of strains 2,12 and 13 were examined and are compared with neighbouring strains and with strain $3001^{\mathrm{T}}$ in Table 1 . The physiological properties of strains $3001^{\mathrm{T}}, 12$ and 13 were similar but quite different from those of strain 2 .

To characterize the strains further, the 16S rRNA genes of strains $3001^{\mathrm{T}}, 2,12$ and 13 were amplified by PCR using synthetic oligonucleotides. The primers used were; 5'-AGAGTTTGATCCTGCTCAG-3' (positions 8 to 26, Escherichia coli numbering system, Brosius et al., 1978) and 5'-GGTTACCTTGTTACGACTT-3' (positions 1509 to 1491). The amplified $1.5 \mathrm{~kb}$ fragments from the $16 \mathrm{~S}$ rRNA genes of these strains were directly cloned into the pT7 Blue

Table 1. Comparison of physiological properties of isolated and related strains

Strains: 1, strain 2; 2, strain 12; 3, strain 13; 4, strain $3001^{\mathrm{T}} ; 5$, Ideonella dechloratans; 6, Leptothrix discophora; 7, Roseateles depolymerans; 8, Aquabacterium citratiphilum; 9, Rubrivivax gelatinosus. Chitosan degradability and quinone type were tested in this study. Other results are taken from Kalmbach et al. (1999), Malmqvist et al. (1994), Spring et al. (1996), Suyama et al. (1999) and Willems et al. (1991a). NT, Not tested; NA, not available.

\begin{tabular}{|c|c|c|c|c|c|c|c|c|c|}
\hline Characteristic & 1 & 2 & 3 & 4 & 5 & 6 & 7 & 8 & 9 \\
\hline Flagella & NT & 1, Polar & 1, Polar & 1, Polar & Several polar & 1, Polar & Several polar & 1, Polar & 1, Polar \\
\hline Sheath formation & - & - & - & - & - & + & - & - & - \\
\hline Polyalkanoate inclusion body & - & - & - & - & - & NA & NA & + & NA \\
\hline $\mathrm{pH}$ for growth & $5-8$ & $5-9$ & $5-9$ & $5-9$ & $5-9$ & NA & $6-8$ & $6 \cdot 5-9 \cdot 5$ & $5-9$ \\
\hline Maximum temperature for growth $\left({ }^{\circ} \mathrm{C}\right)$ & 37 & 34 & 34 & 34 & 42 & NA & 45 & 34 & 37 \\
\hline \multicolumn{10}{|l|}{ Enzyme activity: } \\
\hline Catalase & + & + & + & + & + & - & - & - & + \\
\hline Oxidase & + & + & + & + & + & + & + & NA & + \\
\hline Urease & + & - & - & - & + & NA & - & $+1-$ & - \\
\hline \multicolumn{10}{|l|}{ Production of: } \\
\hline Dihydroxyacetone & + & - & - & - & - & NA & - & $\mathrm{NA}$ & - \\
\hline Indole & + & - & - & - & - & NA & - & $\mathrm{NA}$ & - \\
\hline 2-Ketogluconate & + & - & - & - & NA & NA & NA & NA & NA \\
\hline \multicolumn{10}{|l|}{ Pigment: } \\
\hline Bacteriochlorophyll $a$ & - & - & - & - & - & + & - & NA & + \\
\hline Fluorescent (King's A and B) & + & - & - & - & NA & NA & NA & NA & NA \\
\hline Nitrate reduction & - & + & + & + & + & - & - & + & - \\
\hline Hydrolysis of Tweens $20,40,80$ & + & + & + & + & + & NA & + & + & + \\
\hline Chitosan degradation & + & + & + & + & - & - & - & NA & - \\
\hline Quinone type & MK-6 & UQ-8 & UQ-8 & UQ-8 & UQ-8 & UQ-8 & UQ-8 & NA & UQ-8, MK-8 \\
\hline DNA G $+\mathrm{C}$ content $(\mathrm{mol} \%)$ & $35 \cdot 6$ & $67 \cdot 4$ & $69 \cdot 1$ & $69 \cdot 2$ & $68 \cdot 1$ & $67 \cdot 8-71 \cdot 1$ & $66 \cdot 2$ & 66 & $70 \cdot 0-72 \cdot 5$ \\
\hline $16 \mathrm{~S}$ rRNA gene similarity to $3001^{\mathrm{T}}(\%)$ & $72 \cdot 0$ & $98 \cdot 9$ & $98 \cdot 7$ & 100 & $93-94$ & $94-95$ & $94-95$ & $93-94$ & $94-95$ \\
\hline
\end{tabular}


T-vector (Novagen). Sequencing was performed by the dideoxy-nucleotide chain-termination method (Sanger et al., 1977) using an ABI Prism 377 DNA sequencer (PerkinElmer). The 16S rRNA gene sequences of the fragments from strain $3001^{\mathrm{T}}(1490 \mathrm{bp})$, strain 2 (1476 bp), strain 12 $(1489 \mathrm{bp})$ and strain 13 (1489 bp) were deposited in GenBank/EMBL/DDBJ. A homology search analysis of the 16S rRNA gene sequences was conducted using the Ribosomal Database Project (RDP) software (Maidak et al., 1999). Phylogenetic trees were constructed from the $16 \mathrm{~S}$ rRNA gene sequences by using the CLUSTAL $\mathrm{W}$ program and the neighbour-joining method (Saitou \& Nei, 1987). The phylogenetic tree suggested the presence of an independent group consisting of strains $3001^{\mathrm{T}}, 12$ and 13 (Fig. 2). The $16 \mathrm{~S}$ rRNA genes of strains 12 and 13 displayed sequence similarities of 98.9 and $98.7 \%$ with strain $3001^{\mathrm{T}}$, respectively. The 16S rRNA gene sequences of strains $3001^{\mathrm{T}}, 12$ and 13 were most closely related to those of Rubrivivax gelatinosus (94-95\% similarity) (Willems et al., 1991a), Leptothrix discophora (94-95 \%) (Emerson \& Ghiorse,1993; Spring et al., 1996), Roseateles depolymerans (94-95\%) (Suyama et al., 1998, 1999), Aquabacterium citratiphilum (93-94\%) (Kalmbach et al., 1999) and Ideonella dechloratans (93-94\%) (Malmqvist et al., 1994) (Fig. 2). The genus Rubrivivax has been proposed for certain strains of phototrophic bacteria that are phenotypically similar to strains of Rhodoferax (Hiraishi, 1994; Hiraishi et al., 1991; Hochkoeppler et al., 1995) and Rhodocyclus (Hiraishi et al.,
1991; Willems et al., 1991a). Strains $3001^{\mathrm{T}}, 12$ and 13 can be easily differentiated from related phototrophic species of Rhodoferax, Rubrivivax and Rhodocyclus mainly on the basis of their failure to grow photosynthetically. We did not detect the specific absorption peak at $870 \mathrm{~nm}$ for bacteriochlorophyll $a$ in cultures of strains $3001^{\mathrm{T}}, 12$ and 13 but the $870 \mathrm{~nm}$ peak was detected in cultured cells of Rst. depolymerans. Strains $3001^{\mathrm{T}}, 12$ and 13 were distinguishable from Rst. depolymerans (Suyama et al., 1998, 1999) mainly by the absence of bacteriochlorophyll $a$ and by some differences in physiological properties such as flagellation, possession of catalase and carbon source utilization. We did not observe large polyalkanoate inclusion bodies in strains $3001^{\mathrm{T}}, 12$ and 13, as found in Aquabacterium (Kalmbach et al., 1999). As strains $3001^{\mathrm{T}}, 12$ and 13 lacked sheath production, they were easily distinguished from genera such as Leptothrix and Sphaerotilus (Rogers \& Anderson, 1976; Siering \& Ghiorse, 1996).

DNA-DNA dot hybridization against chromosomal DNAs from various strains was performed using chromosomal DNA of strain $3001^{\mathrm{T}}$ as a probe. Comamonas testosteroni ATCC $11996^{\mathrm{T}}$, I. dechloratans CCUG $30898^{\mathrm{T}}$, Rvi. gelatinosus ATCC $17011^{\mathrm{T}}$ and V. paradoxus IAM $12373^{\mathrm{T}}$ were used as reference strains. Purified chromosomal DNAs $(12 \cdot 5 \mu \mathrm{g})$ were cross-linked to a nitrocellulose membrane by UV light, pre-hybridized at $42^{\circ} \mathrm{C}$ for $1 \mathrm{~h}$ and then incubated at $42^{\circ} \mathrm{C}$ for $14 \mathrm{~h}$ in a hybridization solution containing $100 \mathrm{ng}$ DNA

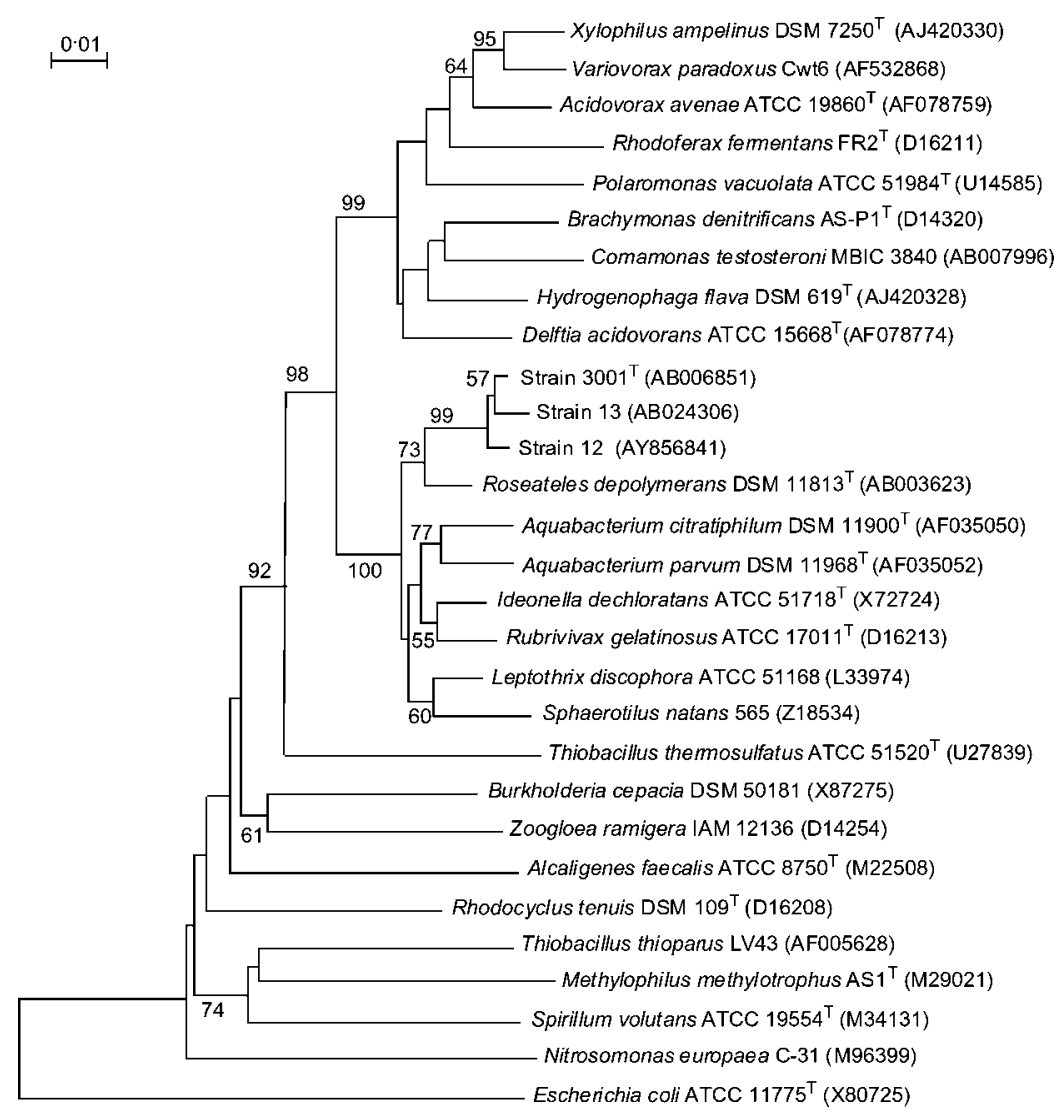

Fig. 2. Phylogenetic position of strain $3001^{\top}$ based on $16 \mathrm{~S}$ rRNA gene sequence. The 16S rRNA gene sequence of strain $3001^{\top}$ was determined and compared with the complete 16S rRNA gene sequences of other related genera. Sequences were aligned by using CLUSTAL $W$ and the tree was constructed by the neighbour-joining method (Saitou \& Nei, 1987). The numbers on the branches are confidence limits (expressed as percentages) estimated from the bootstrap analysis performed with 1000 replicates. Bar, 1 nucleotide substitution per 100 nucleotides. 
probe. Spots were detected by the ECL system (Amersham). The relative intensity of hybridization was estimated by densitometry to be $100,3 \cdot 8,78 \cdot 8,96 \cdot 2,7 \cdot 7,5 \cdot 8,19 \cdot 2$ and $7 \cdot 7 \%$ for strains $3001^{\mathrm{T}}, 2,12,13$, C. testosteroni, I. dechloratans, Rvi. gelatinosus and V. paradoxus, respectively. This result indicates that strains $3001^{\mathrm{T}}, 12$ and 13 are within the same genus, but different from the other tested strains.

To confirm this result, solution DNA-DNA hybridization was performed as described previously (Tanasupawat et al., 1992). In brief, chromosomal DNAs from various strains were prepared and hybridized in solution with ${ }^{32} \mathrm{P}$-labelled chromosomal DNA from strain $3001^{\mathrm{T}}$. Hybridized DNAs were digested by a standard amount of S1 nuclease. Nondigested DNA was sedimented by trichloroacetic acid and the remaining radioactivity was counted. DNA-DNA hybridization with strain $3001^{\mathrm{T}}$ was calculated to be $23 \cdot 3,71 \cdot 9$, $78 \cdot 1,44 \cdot 7,43 \cdot 7,39 \cdot 0$ and $41 \cdot 0 \%$ for strains $2,12,13, C$. testosteroni, I. dechloratans, Rvi. gelatinosus and V. paradoxus, respectively. These values were the means of three independent experiments. DNA-DNA hybridization values of over $70 \%$ suggest that two strains belong to the same species and values lower than $50 \%$ suggest that the strains belong to different genera. These results indicate that strains $3001^{\mathrm{T}}, 12$ and 13 are very closely related and are different from strain 2, C. testosteroni, I. dechloratans, Rvi. gelatinosus and $V$. paradoxus. Strain 2 was also isolated as a chitosanolytic bacterium using the same screening test, but seemed to belong to the genus Flavobacterium based on its $16 \mathrm{~S}$ rRNA gene sequence. For strain 2, the highest sequence similarity found for the $16 \mathrm{~S}$ rRNA gene was with that of Flavobacterium indologenes (98\%).

The DNA G $+\mathrm{C}$ content of the strains was determined by the method of Mesbah \& Whitman (1989). The DNA G + C content for strains $3001^{\mathrm{T}}, 2,12$ and 13 was $69 \cdot 2,35 \cdot 6,67 \cdot 4$ and $69 \cdot 1 \mathrm{~mol} \%$, respectively. These results are consistent with the suggestion that strains $3001^{\mathrm{T}}, 12$ and 13 are the same species.

The major fatty acids of strains $3001^{\mathrm{T}}, 2,12$ and 13 were examined according to the method of Takeuchi et al. (1995) and found to be quite similar, except for those of strain 2 . The major components for strain $3001^{\mathrm{T}}$ were palmitic acid (16:0), palmitoleic acid $(16: 1), 3-\mathrm{OH} 10: 0$ and $3-\mathrm{OH}$ 14:0. A similar distribution of fatty acid composition was observed for Rvi. gelatinosus (Hiraishi et al., 1991). L. discophora contains 3-hydroxydecanoic acid (3-OH 10:0) as the major 3-OH fatty acid (Stead, 1992). Strain 2 had a totally different fatty acid composition and contained iso $15: 0$ non-polar fatty acids, iso $15: 0$ and iso $17: 03$-hydroxy acids.

The quinone type present in the isolated strains was determined by HPLC (Okada et al., 1997). Strains $3001^{\mathrm{T}}, 12$ and 13 all contained UQ-8 as the major ubiquinone, while strain 2 contained MK-6. As no menaquinone was detected in strains $3001^{\mathrm{T}}, 12$ and 13 , they were clearly differentiated from Rvi. gelatinosus, which contains both UQ-8 and MK-8
(Hiraishi et al., 1991). UQ-8 is also found in species related to $C$. testosteroni and $V$. paradoxus, but the fatty acid composition (3-OH 10:0) and biological features of these strains are quite different from those of strains $3001^{\mathrm{T}}, 12$ and 13.

The chitosan-degrading activity of Rvi. gelatinosus, I. dechloratans, L. discophora, Sphaerotilus natans, V. paradoxus and Rst. depolymerans was tested and no activity could be detected.

A comparison of the physiological properties, phylogenetic relationships, DNA G $+\mathrm{C}$ content, quinone species, wholecell fatty acid profiles and DNA-DNA hybridization of strains $3001^{\mathrm{T}}, 12$ and 13 showed them to be markedly different from closely related genera such as Rubrivivax, Rhodoferax, Sphaerotilus, Variovorax, Ideonella, Roseateles and Aquabacterium. For these reasons, we propose that strains $3001^{\mathrm{T}}, 12$ and 13 be given the name Mitsuaria chitosanitabida and that they be placed in a new genus within the 'Betaproteobacteria'.

\section{Description of Mitsuaria gen. nov.}

Mitsuaria (Mit'su.ar.i.a. L. fem. suff. -aria belonging to; N.L. fem. n. Mitsuaria belonging to Matsue City, an inhabitant of Matsue City, the source of the soil samples from which the organism was isolated).

Cells are $0 \cdot 7-1 \cdot 0 \mu \mathrm{m}$ wide and $2 \cdot 0-4 \cdot 0 \mu \mathrm{m}$ long. Cells are motile by means of a single polar flagellum. Endospores are not formed. Gram-negative. Obligately aerobic. Oxidase and catalase-positive. The major respiratory quinone is UQ-8. The major cellular hydroxy fatty acids are $3-\mathrm{OH}$ 10:0 and 3-OH 14:0. The DNA G $+\mathrm{C}$ content of the type strain is $69 \cdot 2 \mathrm{~mol} \%$ (as determined by HPLC). The species is phylogenetically related to members of the 'Betaproteobacteria'. The type species is Mitsuaria chitosanitabida.

\section{Description of Mitsuaria chitosanitabida sp. nov.}

Mitsuaria chitosanitabida (chi'to.san.it.ab'i.da. N.L. n. chitosanum chitosan; L. adj. tabida dissolving, decaying, consuming, putrefying; N.L. fem. adj. chitosanitabida dissolving chitosan, a polysaccharide found in Crustacea, which is a deacetylated derivative of chitin).

Displays the following properties in addition to those given in the genus description. Colonies are circular with entire margins and are light brown in colour. Phototrophic growth is negative. Good growth occurs on nutrient agar at 20 $30{ }^{\circ} \mathrm{C}$ between $\mathrm{pH} 5 \cdot 0$ and $9 \cdot 0$. Nitrate is reduced to nitrite. $\mathrm{H}_{2} \mathrm{~S}$ is not produced. No production of urease, indole, 3ketolactose, dihydroxyacetone and 2-ketogluconate. VogesProskauer and methyl red tests are negative. Tweens 40, 60 and 80 are hydrolysed. Fluorescent pigment is not produced on King's media A or B. D-Glucose, D-glucosamine, maltose and glycerol are assimilated, but L-arabinose, D-fructose, D-sorbitol, D-raffinose, D-xylose, D-galactose, sucrose, 
D-mannose, $N$-acetyl-D-glucosamine, lactose and $\mathrm{n}$ hexadecane are not assimilated. The major respiratory quinone is ubiquinone 8 . The major cellular hydroxy fatty acids are 3-OH 10:0 and 3-OH 14:0. The G $+\mathrm{C}$ content of the DNA of the type strain is $69 \cdot 2 \mathrm{~mol} \%$ (as determined by HPLC).

The type strain, $3001^{\mathrm{T}}\left(=\operatorname{IAM} 14711^{\mathrm{T}}=\right.$ ATCC BAA $\left.-476^{\mathrm{T}}\right)$, was isolated from soil from Matsue City, Japan.

\section{Acknowledgements}

Rubrivivax gelatinosus strain ATCC $17011^{\mathrm{T}}$ was kindly donated by Dr A. Hayashi. We thank Yukari Ohta and Kazutaka Shigeru for technical assistance. We are grateful to Dr Aiko Hirata, Institute of Molecular and Cellular Biosciences, University of Tokyo, for help with electron microscopy.

\section{References}

Brosius, J., Palmer, M. L., Kennedy, P. J. \& Noller, H. F. (1978). Complete nucleotide sequence of a $16 \mathrm{~S}$ ribosomal RNA gene from Escherichia coli. Proc Natl Acad Sci U S A 75, 4801-4805.

Emerson, D. \& Ghiorse, W. C. (1993). Role of disulfide bonds in maintaining the structural integrity of the sheath of Leptothrix discophora SP-6. J Bacteriol 175, 7819-7827.

Hiraishi, A. (1994). Phylogenetic affiliations of Rhodoferax fermentans and related species of phototrophic bacteria as determined by automated 16S rRNA sequencing. Curr Microbiol 28, 25-29.

Hiraishi, A., Hoshino, Y. \& Satoh, T. (1991). Rhodoferax fermentans gen. nov., sp. nov., a phototrophic purple nonsulfur bacterium previously referred to as the "Rhodocyclus gelatinosus-like" group. Arch Microbiol 155, 330-336.

Hochkoeppler, A., Kofod, P., Ferro, G. \& Ciurli, S. (1995). Isolation, characterization, and functional role of the high-potential iron-sulfur protein (HiPIP) from Rhodoferax fermentans. Arch Biochem Biophys 322, 313-318.

Kalmbach, S., Manz, W., Wecke, J. \& Szewzyk, U. (1999). Aquabacterium gen. nov., with description of Aquabacterium citratiphilum sp. nov., Aquabacterium parvum sp. nov. and Aquabacterium commune sp. nov., three in situ dominant bacterial species from the Berlin drinking water system. Int J Syst Bacteriol 49, 769-777.

Maidak, B. L., Cole, J. R., Parker, C. T., Jr \& 11 other authors (1999). A new version of the RDP (Ribosomal Database Project). Nucleic Acids Res 27, 171-173.

Malmqvist, A., Welander, T., Moore, E., Ternstrom, A., Molin, G. \& Stenstrom, I. M. (1994). Ideonella dechloratans gen. nov., sp. nov., a new bacterium capable of growing anaerobically with chlorate as an electron acceptor. Syst Appl Microbiol 17, 58-64.

Mesbah, M. \& Whitman, W. B. (1989). Measurement of deoxyguanosine/thymidine ratios in complex mixtures by highperformance liquid chromatography for determination of the mole percentage guanine + cytosine of DNA. J Chromatogr 479, 297-306.

Okada, K., Minehira, M., Zhu, X., Suzuki, K., Nakagawa, T., Matsuda, H. \& Kawamukai, M. (1997). The ispB gene encoding octaprenyl diphosphate synthase is essential for growth of Escherichia coli. J Bacteriol 179, 3058-3060.

Park, J. K., Shimono, K., Ochiai, N., Shigeru, K., Kurita, M., Ohta, Y., Tanaka, K., Matsuda, H. \& Kawamukai, M. (1999). Purification, characterization and gene analysis of a chitosanase (ChoA) from Matsuebacter chitosanotabidus 3001. I Bacteriol 181, 66426649.

Rogers, S. R. \& Anderson, J. J. (1976). Measurement of growth and iron deposition in Sphaerotilus discophorus. J Bacteriol 126, 257-263.

Saitou, N. \& Nei, M. (1987). The neighbor-joining method: a new method for reconstructing phylogenetic trees. Mol Biol Evol 4, 406-425.

Sanger, F., Nicklen, S. \& Coulson, A. R. (1977). DNA sequencing with chain-terminating inhibitors. Proc Natl Acad Sci U S A 74, 5463-5467.

Shimono, K., Shigeru, K., Tsuchiya, A., Itou, N., Ohta, Y., Tanaka, K., Nakagawa, T., Matsuda, H. \& Kawamukai, M. (2002a). Two glutamic acids in chitosanase A from Matsuebacter chitosanotabidus 3001 are the catalytically important residues. J Biochem 131, 87-96.

Shimono, K., Matsuda, H. \& Kawamukai, M. (2002b). Functional expression of chitinase and chitosanase, and their effects on morphologies in the yeast Schizosaccharomyces pombe. Biosci Biotechnol Biochem 66, 1143-1147.

Siering, P. L. \& Ghiorse, W. C. (1996). Phylogeny of the SphaerotilusLeptothrix group inferred from morphological comparisons, genomic fingerprinting, and $16 \mathrm{~S}$ ribosomal DNA sequence analyses. Int J Syst Bacteriol 46, 173-182.

Spring, S., Kämpfer, P., Ludwig, W. \& Schleifer, K. H. (1996). Polyphasic characterization of the genus Leptothrix: new descriptions of Leptothrix mobilis sp. nov. and Leptothrix discophora sp. nov. nom. rev. and emended description of Leptothrix cholodnii emend. Syst Appl Microbiol 19, 634-643.

Stead, D. E. (1992). Grouping of plant-pathogenic and some other Pseudomonas spp. by using cellular fatty acid profiles. Int J Syst Bacteriol 42, 281-295.

Suyama, T., Tokiwa, Y., Ouichanpagdee, P., Kanagawa, T. \& Kamagata, Y. (1998). Phylogenetic affiliation of soil bacteria that degrade aliphatic polyesters available commercially as biodegradable plastics. Appl Environ Microbiol 64, 5008-5011.

Suyama, T., Shigematsu, T., Takaichi, S., Nodasaka, Y., Fujikawa, S., Hosoya, H., Tokiwa, Y., Kanagawa, T. \& Hanada, S. (1999). Roseateles depolymerans gen. nov., sp. nov., a new bacteriochlorophyll $a$-containing obligate aerobe belonging to the $\beta$-subclass of the Proteobacteria. Int J Syst Bacteriol 49, 449-457.

Takeuchi, M., Sakane, T., Yanagi, M., Yamasato, K., Hamana, K. \& Yokota, A. (1995). Taxonomic study of bacteria isolated from plants: proposal of Sphingomonas rosa sp. nov., Sphingomonas pruni sp. nov., Sphingomonas asaccharolytica sp. nov., and Sphingomonas mali sp nov. Int J Syst Bacteriol 45, 334-341.

Tanasupawat, S., Hashimoto, Y., Ezaki, T., Kozaki, M. \& Komagata, K. (1992). Staphylococcus piscifermentans sp. nov., from fermented fish in Thailand. Int J Syst Bacteriol 42, 577-581.

Willems, A., Gillis, M. \& De Ley, J. (1991a). Transfer of Rhodocyclus gelatinosus to Rubrivivax gelatinosus gen. nov., comb. nov., and phylogenetic relationships with Leptothrix, Sphaerotilus natans, Pseudomonas saccharophila, and Alcaligenes latus. Int $J$ Syst Bacteriol 41, 65-73.

Willems, A., De Ley, J., Gillis, M. \& Kersters, K. (1991b). Comamonadaceae, a new family encompassing the acidovorans rRNA complex, including Variovorax paradoxus gen. nov., comb. nov., for Alcaligenes paradoxus (Davis 1969). Int J Syst Bacteriol 41, 445-450.

Willems, A., Goor, M., Thielemans, S., Gillis, M., Kersters, K. \& De Ley, J. (1992). Transfer of several phytopathogenic Pseudomonas 
species to Acidovorax as Acidovorax avenae subsp. avenae subsp. nov., comb. nov., Acidovorax avenae subsp. citrulli, Acidovorax avenae subsp. cattleyae, and Acidovorax konjaci. Int J Syst Bacteriol 42, 107-119.
Yun, C.-S., Amakata, D., Matsuo, Y., Matsuda, H. \& Kawamukai, M. (2005). New chitosan-degrading strains that produce chitosanases similar to ChoA of Mitsuaria chitosanitabida. Appl Environ Microbiol (in press). 